\title{
Criss-cross heart associated with Taussig-Bing anomaly - double rarities in a single patient
}

\section{Wada serca typu criss-cross heart połączona z zespołem Taussig-Binga - dwie rzadkie anomalie u jednego pacjenta}

\author{
Santosh Kumar Sinha, Karandeep Singh, Amit Goel, Mukesh Jitendra Jha, \\ Divendu Khanra, Chandra Mohan Varma \\ Department of Cardiology, LPS Institute of Cardiology, G.S.V.M. Medical College, Kanpur, India
}

\begin{abstract}
Criss-cross heart is an extremely rare anomaly, characterized by an abnormal rotation of the ventricular mass along its major axis that is the apical part twists about their long axes while the base of the heart and the atrio-ventricular (AV) valves remains fixed. Due to the complex structural changes and rarity of the anomaly, the rotation of ventricular axis is often misdiagnosed. Though associated with multitudes of ventriculo-arterial discordances; we report an extremely rare case of criss-cross heart presented in late infancy associated with Taussig-Bing anomaly which has never been reported earlier in the literature to the best of our knowledge.
\end{abstract}

Key words: atrial situs solitus, criss-cross heart, DORV, Taussig-Bing anomaly

Folia Cardiologica 2017; 12, 3: 277-280

\section{Introduction}

Criss-cross atrioventricular (AV) connection is a condition in which the ventricular inflow tracts are crossed, hence the name criss-cross. Ventricles are positioned contra laterally to the atria to which they are connected. The most common is atrial situs solitus presentation with right atrium (RA) connected to left-sided right ventricle (RV) with anterior tricuspid valve and left atrium (LA) connected to right-sided left ventricle (LV) with mitral valve oriented in the posterior direction. There is crossing of systemic and pulmonary venous blood without mixing in the AV valves [1]. The VA connection is extremely variable: discordant being the most common type followed by double outlet right ventricle (DORV) and many more but Taussig-Bing anomaly, which is another rare congenital heart disease has never been reported.

\section{Case report}

Nine month male baby was admitted with fever and tachypnea. She was product of non-consanguineous marriage and was delivered normally. She weighed $3.9 \mathrm{~kg}$ while at birth $2.2 \mathrm{~kg}$. There was history of diaphoresis while feeding and recurrent episodes of chest infection. Her parents noted mild cyanosis during her early infancy. Her $\mathrm{SO}_{2}$ was $89 \%$. On examination, pulse rate was 134 with all pulses preserved. Jugular venous pulse was elevated. Right ventricular heave was conspicuous. There was left ventricular (LV) type of apical impulse. Thrill was present in left third intercostals space. $\mathrm{P}_{2}$ component of $\mathrm{S}_{2}$ was loud with splitting preserved. Systolic murmur was heard in base. There were bi-basal crepts. Routine blood investigation indicated mild leukocytosis. Chest X-ray PA view showed cardiomegaly (cardiothoracic ratio 0.58 )

Address for correspondence: Santosh Kumar Sinha MD, FAESC, Asst. Professor, Department of Cardiology, LPS Institute of Cardiology, G.S.V.M. Medical College, G.T. Road, Kanpur, Uttar Pradesh 208002, India, e-mail: fionasan@rediffmail.com 

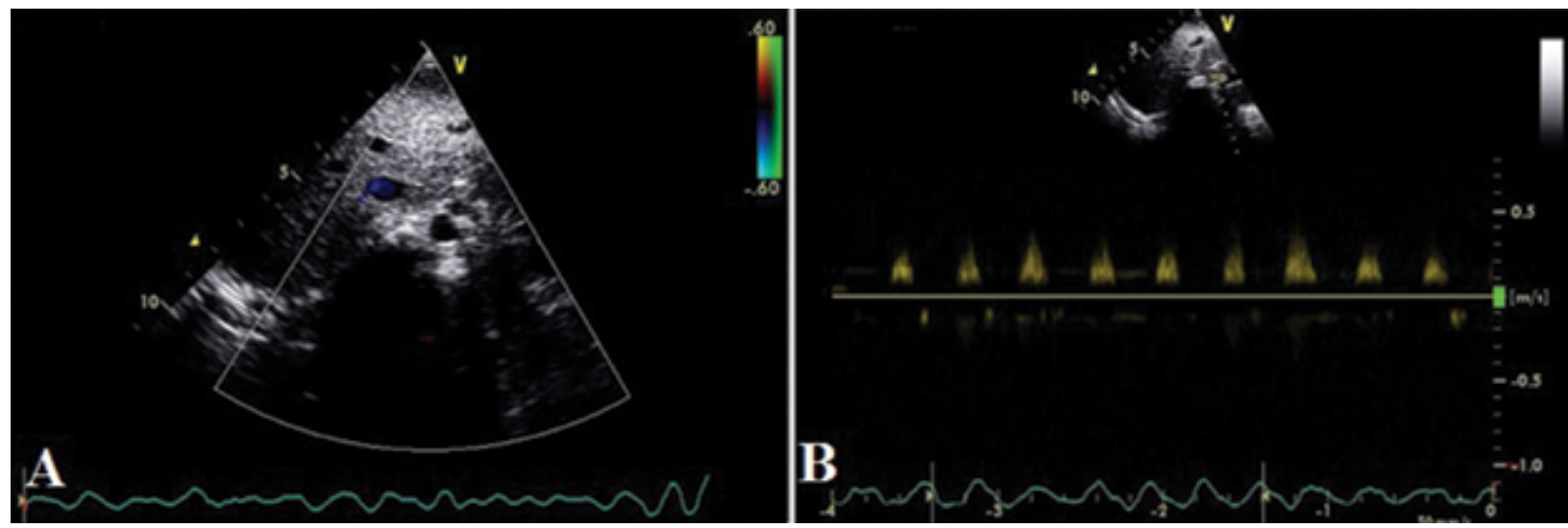

Figure 1A, B. Visceroatrial situs solitus (A); no coarctation (B)

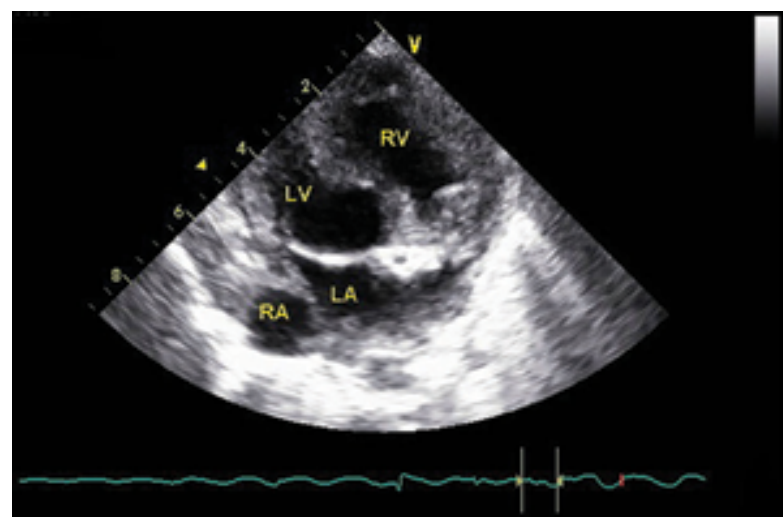

Figure 2. Atrial situs solitus with ventricles appeared to have been rotated about their long axes i.e. Criss-cross heart. Right ventricle (RV) which is left to the left ventricle (LV)

with pulmonary plethora. Electrocardiogram showed right axis deviation, clockwise loop, right ventricular hypertrophy and well preserved $\mathrm{R}$ waves in $\mathrm{V} 5-\mathrm{V} 6$ reflecting $\mathrm{LV}$ volume overload.

\section{Echocardiogram}

The visceroatrial situs was solitus with levocardia (Fig. 1A). Sub costal view showed atrio-ventricular concordance. Cardiac chambers were identified on their morphological characteristics. Right atrium (RA) was on the right side and was connected to right ventricle (RV) which was left to the LV; left atrium (LA) was on the left side and connected to LV which was right to the RV. Ventricles appeared to have been rotated about their long axes without concomitant motion of the AV valve annuli, producing actual crossing of the ventricular inflow tracts therefore establishing the diagnosis of criss-cross heart (Fig. 2). When great arterial connections were probed, both Ao and pulmonary artery (PA) were seen arising from right ventricle (Fig. 3). There was ventricular septal defect which was sub pulmonary (Fig. 3). Pulmonary trunk was seen over-riding sub pulmonary ventricular septal defect (Fig. 3). Pulmonary trunk was

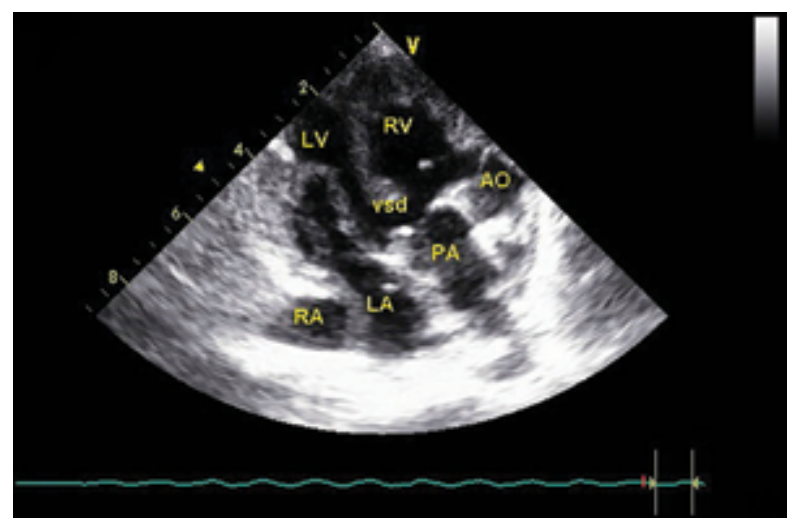

Figure 3. Criss-cross heart with sub pulmonary ventricular septal defect. Pulmonary trunk is seen over-riding sub pulmonary ventricular septal defect

situated right, posterior and inferior to the Ao (Fig. 4). There was no right ventricular outflow tract (RVOT) obstruction (Fig. 1B). Also there was no pulmonary-mitral continuity. The great arterial connections confirmed the diagnosis of Taussig-Bing anomaly. There was no coarctation (Fig. 1B). When agitated saline as contrast was injected in right arm, it was seen coursing from RA to RV to Ao thus further confirming atrio-ventricular concordance (Fig. 5). Biventricular systolic function was qualitatively normal.

\section{Discussion}

The criss-cross heart is an extremely rare malformation but well described morphologically. It was first described by Lev \& Rowlatt [2] in 1961, but it was only in 1974 that Anderson et al. first used the term criss-cross heart which accounts for less than $0.1 \%$ of congenital heart defects [1]. It is especially important anomaly because it illustrates a key component essential to understand congenital defects: the difference between situs concordance and alignment concordance; both concepts being important for deciphering and understanding congenital anomalies. 


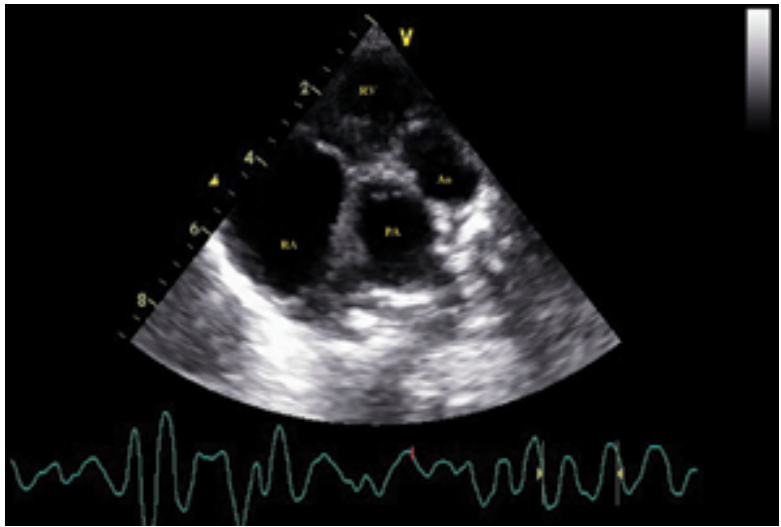

Figure 4. Pulmonary trunk is situated right, posterior and inferior to the aorta (Ao)

In most patients with criss-cross heart, the AV segmental situs is consistent with the AV alignments. Therefore in patients with atrial situs solitus and $d$-looped ventricles, RA opens into RV and LA opens into LV i.e. concordant AV alignment. Similarly patients with atrial situs solitus and I-looped ventricles, RA is aligned with LV and LA aligned with RV i.e. discordant AV alignment . However, disharmony between the segmental situs and the AV alignment may exist. Therefore in rare situation, patients with situs solitus of atria but I-looped ventricles will have AV alignment concordance. That is, despite having segmental situs discordance, RA and LA are aligned with RV and LV respectively. Similarly, atrial situs solitus with $d$-looped ventricles, RA and LA will be connected with LV and RV respectively.

Criss-cross heart therefore illustrates an important concept that AV segmental situs is not always predictive of AV alignment therefore both needs different description and elucidation. The diagnosis of criss-cross heart is based on the intersection of the axes of the ventricular entries. In contrast to normal heart where these axes are virtually parallel, $\mathrm{CCH}$ is characterized by a spatial change of the ventricular mass that guides or appears to guide, each ventricle in a contra lateral position in relation to the corresponding atrium. While the base of the heart remains unchanged in its spatial position, the ventricles appear to have been twisted along their longitudinal axis. This promotes a change in hemodynamics characterized by crossing flows through the atrioventricular valves, resulting in the false impression that each atrium is being directed to the contra lateral ventricle [3].

A review of the literature revealed that this anomaly rarely occurs in isolation. Most patients have ventricular septal defects, transposition of the great arteries, double-outlet right ventricle, hypo plastic right ventricle, pulmonary stenosis and tricuspid hypoplasia. Other associated defects, although less frequent, are straddling mitral or

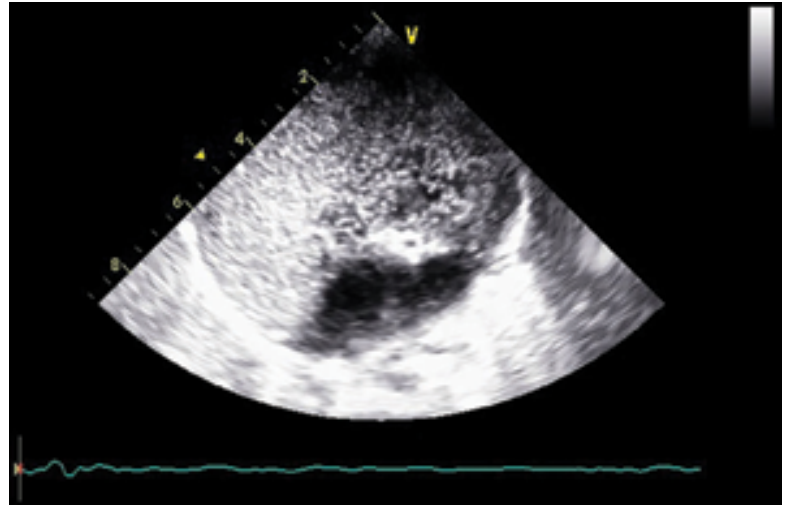

Figure 5. Saline contrast being seen coursing from right atrium $(\mathrm{RA})$ to right ventricle $(\mathrm{RV})$ to aorta $(\mathrm{Ao})$ thus further confirming atrio-ventricular concordance

tricuspid valve, sub aortic stenosis, aortic arch obstruction and mitral stenosis [3-6]. The diagnosis becomes more difficult due to the similarity of the clinical presentation of the different connections abnormalities [7, 8]. The transthoracic echocardiography can be used to identify the position and morphology of all cardiac chambers, AV valves, in addition to the connections between chambers and vessels. The sub costal window will determine the location of the heart apex and assess mainly the ventricles characteristics. The morphological features help determining the morphologic ventricle characteristics [7]. The great arteries connections are better visualized in the parasternal window $[9,10]$. The differential diagnosis of criss-cross heart should include straddling atrioventricular valve, double atrial outlet where an outlet orifice apparently crosses the other valve, and severe forms of Ebstein anomaly on which the tricuspid valve opens to the infundibulum, giving the appearance of crossing the valves [10].

In Taussig Bing anomaly, as the flow is from RV to aorta and LV blood preferentially enters the lung, cyanosis dates since birth. Consequently, neonates typically present with cyanosis, systolic murmur and heart failure. As the pulmonary vascular resistance increases, PBF curtails and cyanosis deepens but longevity prolongs. Clinically they may resemble transposition of the great arteries, but a scan from posterior to anterior in the apical four-chamber view shows the crossing axes of the atrioventricular valves. Similarly Doppler color flow mapping has been reported to facilitate detection of crossing of the inflow streams.

Taussig-Bing is a rare condition and accounts for $1-1.5 \%$ of all congenital cardiac malformations. The distinctive features of the Taussig-Bing malformation are true double outlet right ventricle, semi lunar valves side-by-side and approximately at the same height, a bilateral conus with approximately equally well-developed muscular sub 
aortic and sub pulmonary conal free walls, and a large sub pulmonary VSD. Despite many years of experience with various management strategies, Taussig-Bing anomaly still continues to pose a considerable challenge to surgeons, largely related to its associated anomalies. Treatment may include initial palliation with a systemic-to-pulmonary shunt to increase pulmonary blood flow and improve cyanosis. This is followed by staged progression toward completion of a Fontan-type operation in the majority. However the two rare cases of the congenital deformities viz. Criss-cross heart and Taussig-Bing anomaly have been reported in isolation but literature review did not show dual occurrence in a single patient till date and our case appears to be the first one such.

\section{Conflict of interest(s)}

None.

\section{Streszczenie}

Wada serca typu criss-cross heart jest bardzo rzadką anomalią polegającą na nieprawidłowej rotacji komór wokół długiej osi serca, przy czym przemieszczeniu ulega koniuszek serca, a podstawa serca i zastawki przedsionkowo-komorowe pozostają na miejscu. Ze względu na złożone zmiany strukturalne oraz rzadkie występowanie tej wady rotacja osi serca często nie zostaje właściwie rozpoznana. Anomalia ta wiąże się z wieloma zaburzeniami przedsionkowo-komorowymi. W niniejszej pracy przedstawiono niezwykle rzadki przypadek wady serca typu criss-cross heart ujawnionej w późnym okresie niemowlęcym, połączonej z zespołem Taussig-Binga. Według najlepszej wiedzy autorów taki przypadek nigdy wcześniej nie był opisywany.

Słowa kluczowe: situs solitus przedsionków, criss-cross heart, DORV, zespół Taussig-Binga

Folia Cardiologica 2017; 12, 3: 277-280

\section{References}

1. Anderson RH, Shinebourne EA, Gerlis LM. Criss-cross atrioventricular relationships producing paradoxical atrioventricular concordance or discordance. Their significance to nomenclature of congenital heart disease. Circulation. 1974; 50(1): 176-180, indexed in Pubmed: 4835263.

2. Lev M, Rowlatt U. The pathologic anatomy of mixed levocardia. Am J Cardiol. 1961; 8(2): 216-263, doi: 10.1016/0002-9149(61)90209-0.

3. Crisscross heart. Orphanet encyclopedia. http://www.orpha.net/ /data/patho/Pro/en/CrissCrossHeart-FRenPro8602.pdf. (February $29^{\text {th }} 2017$ ).

4. Croti UA, Mattos SS, Pinto VC, Aiello AD. Cirurgia cardiovascular pediátrica. $1^{\text {a }}$ ed. Roca, São Paulo 2008.

5. Gatzoulis MA, Webb GD, Broberg CS, et al. Cases in adult congenital heart disease. Complex congenital heart conditions. 2010; 1: $278-280$.
6. Angelini P, Lopez A, Lufschanowski R, et al. Coronary arteries in crisscross heart. Tex Heart Inst J. 2003; 30(3): 208-213, indexed in Pubmed: 12959204.

7. Wallis GA, Debich-Spicer D, Anderson RH. Congenitally corrected transposition. Orphanet J Rare Dis. 2011; 6: 22, doi: 10.1186/17501172-6-22, indexed in Pubmed: 21569592.

8. Valenzuela JMM, Lucas E, Bomfin Jr EJ. Criss-cross heart: diagnóstico fetal. Rev Bras Ecocardiogr Imagem Cardiovasc. 2009; 22(2): 51-56.

9. Carminati M, Valsecchi 0 , Borghi A, et al. Cross-sectional echocardiographic study of criss-cross hearts and superoinferior ventricles. Am J Cardiol. 1987; 59(1): 114-118, indexed in Pubmed: 3812221.

10. Attie F, Zabal C, Buendia A. Cardiologia pediátrica. Diagnóstico y tratamiento. Panamericana, México 1993: 353-362. 